\title{
KVSA VERTAALPRYS / CASA TRANSLATION PRIZE
}

The CASA translation competition is sponsored annually for the best student translation from, or into, either Latin or Classical Greek.

\section{PLAUTUS: MILES GLORIOSUS 2.2}

\section{Simon Idema (North-West University)}

\section{Introduction}

Miles Gloriosus is a Roman Comedy, written by Plautus in the late $3^{\text {rd }}$ century BC. The action of the play centres around a young Athenian man whose girlfriend (Rosie) is abducted by the miles (colonel), an arrogant and overbearing soldier, while the young man is away on a political errand. Whilst trying to warn his master, the young man's servant (Micky) is captured by pirates and taken to Ephesus where he is sold to the same miles. After receiving a letter from his slave, the young man travels to Ephesus and takes up lodging with a family friend (Mr. Brown) who happens to be the miles' neighbour. In order for the lovers to see each other, the young man's servant makes a hole in the wall between the houses. In the following scene, the lovers have been caught in the act by one of the miles' servants, and the owner of the house (the family member) is worrying what to do.

The following English translation of Plautus' Miles Gloriosus 2.2 forms part of an Honours' mini-dissertation in which I will focus on conceptual metaphor and the translation thereof. The Miles Gloriosus serves as a fitting source for this analysis, since Plautus' comedies are among some of the oldest Latin texts, and since they were written in a language reflecting the tone of daily speech, less formal than that of Cicero and Virgil, that contained various old forms and constructions (Hammond et al., 1963:39). Even though the focus of the assignment will be on novel (or literary) metaphors and not necessarily on metaphors from everyday discourse, novel metaphors are often mere systematic extensions of the existing conceptual mappings on which everyday metaphors are based (Lakoff \& Johnson 1999:66). An analysis of the conceptual metaphors in the text may therefore provide valuable insight into the culture's conceptualisation of various abstract concepts. The Miles Gloriosus 2.2 is of particular interest to this analysis since it contains a description of the making of a plan (a complex cognitive action). In this short passage, the act of thinking is described in several different ways, including motion, perception, object-manipulation, eating, and calculation. I hope to show that an understanding and translation of these concepts may lead to a translation that more accurately transposes the Latin figurative language into contemporary English. The focus of the translation will therefore be on preserving 
the meaning of the text (jokes, metaphors, idioms), rather than the form (exact words, syntax, grammatical constructions).

\section{Source text ${ }^{1}$}

Periplectomenus Ni hercle diffregeritis talos posthac quemque in tegulis videritis alienum, ego vostra faciam latera lorea. mi equidem iam arbitri vicini sunt meae quid fiat domi, ita per impluvium intro spectant. nunc adeo edico omnibus: quemque a milite hoc videritis hominem in nostris tegulis, extra unum Palaestrionem, huc deturbatote in viam. quod ille gallinam aut columbam se sectari aut simiam dicat, disperiistis ni usque ad mortem male mulcassitis. atque adeo, ut ne legi fraudem faciant aleariae, adcuratote ut sine talis domi agitent convivium.

Pal. Nescioquid malefactum a nostra hic familiast, quantum audio: ita hic senex talos elidi iussit conservis meis; sed me excepit: nihili facio, quid illis faciat ceteris. adgrediar hominem. Per. Estne advorsum hic qui advenit Palaestrio? Pal. Quid agis, Periplectomene? Per. Hau multos homines, si optandum foret, nunc videre et convenire quam te mavellem. Pal. Quid est? quid tumultuas cum nostra familia? Per. Occisi sumus.

Pal. Quid negotist? Per. Res palamst. Pal. Quae res palam est?

Per. De tegulis modo nescio quis inspectavit vostrum familiarium per nostrum impluvium intus apud nos Philocomasium atque hospitem osculantis. Pal. Quis homo id vidit? Per. Tuos conservos.

Pal. Quis is homost? Per. Nescio, ita abripuit repente sese subito.

Pal. Suspicor me periisse. Per. Vbi abit, conclamo:

'heus quid agis tu' inquam 'in tegulis?' ille mihi abiens ita respondit 'se sectari simiam.'

Pal. Vae mihi misero, quoi pereundumst propter nihili bestiam. sed Philocomasium hicine etiam nunc est? Per. Quom exibam, hic erat Pal. I sis, iube transire huc quantum possit, se ut videant domi familiares, nisi quidem illa nos volt, qui servi sumus,

The text is taken from Hammond et al. 1963. Previous translations of the text include Riley 1912, Nixon 1963, and De Melo 2011. While the earlier translations by Riley and Nixon are now mostly outdated due to being too literal, the more recent translations by De Melo often fail to capture the essence of some metaphors, while glossing over others entirely. 
propter amorem suom omnis crucibus contubernalis dari.

Per. Dixi ego istuc. - Nisi quid aliud vis ... Pal. Volo. hoc ei profecto ut ne quoquam de ingenio degrediatur muliebri earumque artem et disciplinam optineat colere. Per. Quem ad modum?

Pal. Vt eum, qui se hic vidit, verbis vincat ne is se viderit. siquidem centiens hic visa sit, tamen infitias eat. os habet, linguam, perfidiam, malitiam atque audaciam, confidentiam, confirmitatem, fraudulentiam.

domi habet animum falsiloquom, falsificum, falsiiurium, domi dolos, domi delenifica facta, domi fallacias. nam mulier holitori numquam supplicat, si quast mala: domi habet hortum et condimenta ad omnis mores maleficos.

Per. Ego istaec, si erit hic, nuntiabo. sed quid est, Palaestrio, quod volutas tute tecum in corde? Pal. Paulisper tace, dum ego mihi consilia in animum convoco et dum consulo quid agam, quem dolum doloso contra conservo parem, qui illam hic vidit osculantem, id visum ut ne visum siet.

Per. Quaere: ego hinc abscessero abs te huc interim. illuc sis vide, quem ad modum astitit, severo fronte curans, cogitans. pectus digitis pultat, cor credo evocaturust foras; ecce avortit: nixus laevo in femine habet laevam manum, dextera digitis rationem computat, feriens femur dexterum. ita vehementer icit: quod agat aegre suppetit. concrepuit digitis: laborat; crebro commutat status, eccere autem capite nutat: non placet quod repperit. quidquid est, incoctum non expromet, bene coctum dabit. ecce autem aedificat: columnam mento suffigit suo. apage, non placet profecto mihi illaec aedificatio; nam os columnatum poetae esse indaudivi barbaro, qoi bini custodes semper totis horis occubant. eugae! euscheme hercle astitit et dulice et comoedice; numquam hodie quiescet prius quam id quod petit perfecerit. habet opinor. age si quid agis, vigila, ne somno stude, nisi quidem hic agitare mavis varius virgis vigilias. tibi ego dico. an me ita tu nescis te adloqui? heus Palaestrio. vigila inquam, expergiscere inquam, lucet hoc inquam. Pal. Audio.

Per. Viden hostis tibi adesse tuoque tergo obsidium? consule, arripe opem auxiliumque ad hanc rem: propere hoc, non placide decet. anteveni aliqua, aliquot saltu circumduce exercitum, 
coge in obsidium perduellis, nostris praesidium para; interclude inimicis commeatum, tibi muni viam qua cibatus commeatusque ad te et legiones tuas tuto possit pervenire: hanc rem age, res subitaria est.

reperi, comminiscere, cedo calidum consilium cito, quae hic sunt visa ut visa ne sint, facta ut facta ne sient. magnam illic homo rem incipissit, magna munit moenia. tute unus si recipere ad te hoc dicis, confidentiast nos inimicos profligare posse. Pal. Dico et recipio ad me. Per. Et ego impetrare dico id quod petis. Pal. At te Iuppiter bene amet! Per. Auden participare me quod commentu's? Pal. Tace, dum in regionem astutiarum mearum te induco, ut scias iuxta mecum mea consilia. Per. Salva sumes indidem.

Pal. Erus meus elephanti corio circumtentust, non suo, neque habet plus sapientiai quam lapis. Per. Ego istuc scio.

Pal. Nunc sic rationem incipisso, hanc instituam astutiam, ut Philocomasio huc sororem geminam germanam alteram dicam Athenis advenisse cum amatore aliquo suo, tam similem, quam lacte lactist; apud te eos hic devortier dicam hospitio. Per. Eugae, eugae, lepide, laudo commentum tuom.

Pal. Vt si illic concriminatus sit advorsum militem meus conservos, eam vidisse hic cum alieno osculari, eam arguam vidisse apud te contra conservom meum cum suo amatore amplexantem atque osculantem. Per. Immo optume! idem ego dicam si ex me exquiret miles. Pal. Sed simillimas dicito esse, et Philocomasio id praecipiendum est ut sciat, ne titubet si exquiret ex ea miles. Per. Nimis doctum dolum. sed si ambas videre in uno miles concilio volet, quid agimus? Pal. Facilest: trecentae possunt causae conligi:

'non domist, abit ambulatum, dormit, ornatur, lavat, prandet, potat: occupatast, operae non est, non potest', quantum vis prolationis, dum modo hunc prima via inducamus vera ut esse credat quae mentibitur.

Per. Placet ut dicis. Pal. Intro abi ergo et, si isti est mulier, eam iube cito domum transire, atque haec ei dice monstra praecipe, ut teneat consilia nostra quem ad modum exorsi sumus de gemina sorore. Per. Docte tibi illam perdoctam dabo. numquid aliud? Pal. Intro ut abeas. Per. Abeo ... Pal. Et quidem ego ibo domum atque hominem investigando operam huic dissimulabiliter dabo, 260 qui fuerit conservos qui hodie sit sectatus simiam. 
nam ille non potuit quin sermone suo aliquem familiarium

participaverit de amica eri, sese vidisse eam

hic in proxumo osculantem cum alieno adulescentulo.

novi morem egomet: 'tacere nequeo solus quod scio.'

si invenio qui vidit, ad eum vineam pluteosque agam:

res paratast, vi pugnandoque hominem caperest certa res.

si ita non reperio, ibo odorans quasi canis venaticus

usque donec persecutus volpem ero vestigiis.

sed fores crepuerunt nostrae, ego voci moderabor meae;

nam illic est Philocomasio custos meus conservos qui it foras.

\section{Translation}

Mr. Brown: ${ }^{2}$ (To his servants) God dammit! If you don't beat the shit out of any stranger you see on this roof again I'll make mincemeat of you! ${ }^{3}$ My god ... the neighbours have become such spectators to our comings and goings that they even watch us from our own roof. Now listen up, all of you. If you see any of the colonel's ${ }^{4}$ men except Micky on my roof, you better knock him into the street. I don't 165 care if he says he's chasing a chicken, a pigeon, or a monkey. You're all dead if you don't beat him within an

2 Periplectomenus, the senex, is the name of the family friend. His name means something along the lines of 'one who embraces', which is fitting because he gives Pleusicles (the young Athenian) a place to stay (Hammond et al., 1963:74). I imagine him as a kind old man, and I have called him Mr. Brown, from Oliver Twist's Mr. Brownlow.

3 He tells his slaves that he will make latera lorea 'thongs from their flanks', which I have translated as 'mak[ing] mincemeat of [them]'.

4 In Miles Gloriosus 1.1.72-78 the miles brags that he has been charged with recruiting mercenaries for the king of Syria (he claims the king begged him); in 4.1.947-950 he reveals that he does not, in fact, lead them himself, but he sends his assistant to escort them to the king. It is rather difficult to draw any definite conclusions regarding the miles' rank from the text since he is a known braggart. In the first scene, he boasts about several military achievements, to which his assistant responds in an aside: quae tu numquam feceris 'which you never did' (1.1.20). Even though it is clear that he has some money (he owns a house, several slaves, and was able to shower Rosie's procuress with gifts), it is likely that most of what he says about himself is a gross exaggeration. I have selected the rank of 'colonel' because it seems senior enough to match the miles' ego and because it is in itself a rather ambiguous rank: it can be used as an honorific ( $c f$. Col. Sanders), it may refer to a senior officer position, or to the highest achievable military rank in some armies. 
Micky: ${ }^{6}$

inch of his life. And make sure to beat him so severely that he can't even break the law by selling his organs on the black market. ${ }^{5}$

(To the Audience) It looks like some terrible crime was committed here by someone from our house, or so I keep hearing. Apparently, this old guy ordered my colleagues' organs repurposed, but not mine. I don't give a damn what he does to the rest of them. I'll approach him.

Mr. Brown: Is that you Micky, coming towards me?

Micky: Mr. Brown, how are you?

Mr. Brown: There are very few men I would rather see now than you, given the choice.

Micky: What's wrong? What's your problem with our house?

Mr. Brown: We're dead.

Micky: What's wrong?

Mr. Brown: We've been made?

Micky: Made? Into what?

Mr. Brown: I don't know how, but someone from your house watched us from the roof and saw Rosie ${ }^{8}$ and my guest kissing.

Micky: Who saw it?

Mr. Brown: One of your colleagues.

Micky: Which one?

Mr. Brown: How should I know? He ducked away immediately.

Micky: I'm so dead.

Mr. Brown: As he was running away I shouted, 'Oi, what are you doing on my roof?' He shouted back, saying that he was chasing a monkey.

Micky: $\quad$ Oh, why me? That I should be damned on account of a 180 stupid animal! Wait, is Rosie still here now?

5 There is a joke here when Mr. Brown tells his servants to break the ankles of any intruders to such a degree that they can't break the gambling laws with their own ankle bones (which were used as dice). Since modern readers might not understand the reference, I have translated it as not being able to sell his organs on the black market.

6 Palaestrio, the name of the servus callidus, means 'wrestler', which is appropriate for a slippery slave full of tricks (Hammond et al., 1963:74). In my translation, I have called him Micky, which reminds me of a cunning cockney crook.

7 Mr. Brown says res palamst 'the matter is open'. There seems to be a play on words here when Micky feigns ignorance in the subsequent line. I have translated it as 'We've been made (discovered)', 'made into what?'.

8 The name of the meretrix, Philocomasium, means 'lover of parties' (Hammond et al., 1963:74), and I have called her Rosie. 
Mr. Brown: When I came outside she was still here.

Micky: Go please, and tell her to go back as quickly as possible so that the household can see that she's home. Unless of course she wants us, who are but poor slaves, to be handed over as bitches to crosses. ${ }^{9}$

Mr. Brown: I already told her that. Now if there's nothing else ...

Micky: $\quad$ There is. Tell her this; that she should make sure not to forget her womanly ways, and that she should continue to make use of her tricks and her training.

Mr. Brown: But why?

Micky:

So that she can convince him, who saw her here, that he did not see her here. And even if she was seen here a hundred times, let her still deny it since she has a face and a tongue for malice, treachery, and cheek, for impudence, obstinacy, and deceit. And if he would accuse her, let her convince him with her vows. She has a mind for false words, false deeds, and false promises. A pantry ${ }^{10}$ full of tricks, manipulation, and deceit. A woman never needs to haggle for a price if she's mischievous. ${ }^{11}$ Her mind is a garden suitable for producing all manner of wickedness.

Mr. Brown: I'll tell her that, if she's here. But Micky, what's weighing you down? ${ }^{12}$

Micky: $\quad$ Shut up for a second, while I gather my thoughts and decide what I should do, and what trap I should lay against my crafty colleague who saw her kissing here, so that that which was seen can be unseen.

Mr. Brown: Go ahead then. I'll give you some space. (To the 200 Audience) Look at him, will you? See how he's standing, frowning, thinking? He taps his chest with his fingers. I think his heart is about to pour out. Look! He shifts. Now leaning to his left, he rests his left hand on his leg. On his 
right hand, he's counting his thoughts, while his other leg is supporting that arm. Oh my! How violently he gestures. Whatever he's getting at ${ }^{13}$ is clearly not good enough. He snaps his fingers. He's annoyed, frequently changing his stance. But look at that; he shakes his head. No, he didn't like that idea. Whatever it is, he won't reveal a half-baked plan. He'll present it to me fully seasoned. ${ }^{14}$ Now look how he's sculpting himself. He's attaching a pillar to his chin. Stop that! I really don't like that manner because it reminds me of a barbaric poet with such a pillared face who had to have two guards with him around the clock. Brilliant! My god, how gracefully he carries himself both befitting a slave and a comedy. He won't rest today until he accomplishes what he set out to do. I think he's got it! Get to it then, if you are doing something. Wake up, and don't fall asleep again unless you would prefer to do it awake, beaten black and blue. I'm talking to you. Don't you get that I'm talking to you? Hey Micky! I'm telling you to wake up! I'm telling you to get up! And I'm telling you that the sun's up!

Micky: $\quad$ Cut it out, I hear you already.

Mr. Brown: Can't you see that the enemy is already here? Laying siege to your arse? Pay attention. Accept some help and support in this matter. Quickly now, this is not something to be taken lightly. Anticipate an ambush, or better yet, lead your army by a different route. Lay siege to your enemies and ready our defences. Cut off your enemies' supplies whilst fortifying the road by which food and provisions can arrive safely for you and your legions. Do this now, the matter is urgent. Find a way, think

13 De Melo 2011:163 translates it as 'he can hardly think of anything to do'. In the context of this passage, agat is likely defined as 'he is driving at' ( $L \& S$ s.v. ago II.D.3). The verb suppetit, from peto 'move towards' (De Vaan 2008:463), means 'it is sufficient' according to $L \& S$ s.v. suppeto I.B. It seems, therefore, that the act of formulating a plan is conceptually structured in terms of movement. Taking this into account, a more appropriate translation would be 'whatever he's getting at is clearly not good enough'.

When Mr. Brown is describing Micky's act of thinking in dialogue 27, he says incoctum non expromet 'he won't reveal it uncooked', which I have translated with the English equivalent of the metaphor 'he won't reveal a half-baked plan'. For bene coctum dabit 'he'll give it well cooked', I have chosen 'fully seasoned' (as in, well versed) as a more appropriate food-related metaphor. 
something up. Present me with a seasoned ${ }^{15}$ plan quickly, so that that which was seen here may be unseen; so that that which was done here may be undone. (To the Audience) That bloke is setting an excellent plan in motion; he's building magnificent fortifications. (To Micky) If you alone merely say that you'll take it upon yourself, I am confident that we can overthrow our enemies.

Micky: $\quad$ I do say so, and I do take it upon myself.

Mr. Brown: Then I do say that you'll obtain that which you seek.

Micky: God bless you.

Mr. Brown: Now, won't you share your plan with me?

Micky:

Keep quiet, while I lead you into the realm of my machinations, so that you may partake in my plan with me.

Mr. Brown: You can count on me.

Micky:

My master has the hide of an elephant, and he has no more sense than a stone.

Mr. Brown: Oh, I'm well aware of that.

Micky:

And so, I'll put my plan in motion and set my trap here. I'll say that someone claiming to be her twin sister has arrived from Athens with her lover to visit Rosie, and that they are similar - two peas in a pod. ${ }^{16}$ And I'll also say that they are staying here as your guests.

Mr. Brown: Well done! Well done! What a genius! I love it!

Micky: $\quad$ And if my colleague should accuse her of kissing another man in front of the Colonel I'll say that he actually saw the sister, who's staying with you, kissing and hugging her lover.

Mr. Brown: Indeed, that is brilliant! I'll say the same thing if the Colonel asks me.

Micky: But it's important that our stories match up, and that Rosie is told in advance so that she knows, and so that she won't hesitate when the Colonel asks her.

15 The Latin reads calidum consilium 'warm plan', which Hammond et al. 1963:98 interprets as meaning 'quick'. Taking the metaphor in line 208 (incoctum non expromet ...) into account, I think 'well thought out' would be a better explanation. I have therefore translated it as a 'seasoned (well versed) plan', sticking to the food metaphor.

16 The Latin metaphor is 'as similar as milk is to milk'. 
Mr. Brown: This is a brilliant plan! But what if the Colonel wants to see both at once, what do we do then?

Micky: That's easy. We can come up with a thousand excuses: ${ }^{17}$ she's not home, she went for a walk, she's sleeping, she's getting dressed, she's taking a bath, she's having lunch, she's drinking, she's busy, she doesn't have the time, or just that she can't do it right now; as many excuses as you like. As long as we go about this the right way, he'll believe us.

Mr. Brown: I like what you're saying.

Micky: Go inside, and if she's there, tell her to go back home quickly, and tell her of the plan. Show her and warn her, so that she can be in on the plan regarding her twin sister that we've set in motion.

Mr. Brown: I'll give her to you well versed in the plan. Now is there anything else?

Micky: $\quad$ See that you go inside.

Mr. Brown: I'm going ...

Micky:

I too will go home, and by launching a covert 260 investigation into the man, I will find out which of my colleagues was chasing the monkey today, since he would hardly be able to resist sharing the gossip about the master's girl with at least some of the household; the fact that he saw her here next door, kissing another man. I know his type. He would think: 'I can't keep quiet about something that only I know.' If I find out who saw it, I'll prepare for battle. The plan is ready, and the enemy is sure to be defeated by force. If, on the other hand, I can't find him, I'll go sniffing like a bloodhound until I'm hot on the fox's trail. But wait, there is a sound at our door. I'll lower my voice. It's Rosie's guard, my colleague, who is 270 coming outside.

\section{BIBLIOGRAPHY}

De Melo, W 2011. Plautus: The merchant, The braggart soldier, The ghost, The Persian. Cambridge, Mass: Harvard University Press.

17 Trecentae (300) is an exaggerated number. In English it is more common to use a thousand for this purpose. 
De Vaan, M 2008. Etymological dictionary of Latin and the other Italic languages. Leiden: Brill.

Hammond, M, Mack, A M, Moskalew, W 1963. Miles Gloriosus. Cambridge, Mass: Harvard University Press.

Lakoff, G, Johnson, M 1999. Philosophy in the flesh: The embodied mind and its challenge to western thought. New York: Basic Books.

Lewis, C T, Short, C 1891 [1879]. A new Latin dictionary. New York: Harper \& Brothers.

Nixon, P (ed. \& tr.) 1963. The merchant, The braggart warrior, The haunted house, The Persian. Vol. III. Cambridge, Mass. \& London.

Riley, H T 1912. The comedies of Plautus. London: G Bell \& Sons. 